\title{
Gender Inequality in Wage Rate in Indonesia
}

\author{
Ahmad Rizki Sridadi ${ }^{1} \&$ Gigih Prihantono ${ }^{2}$ \\ ${ }^{1}$ Faculty Economic and Business Universitas Airlangga, Indonesia \\ Correspondence: Gigih Prihantono, Faculty Economic and Business Universitas Airlangga, Indonesia. E-mail: \\ gigih.pri@feb.unair.ac.id
}

Received: January 16, 2018

Accepted: February 20, 2018

Online Published: February 25, 2018

doi:10.5539/ijbm.v13n3p160

URL: https://doi.org/10.5539/ijbm.v13n3p160

\begin{abstract}
Education is an indicator of advanced development, as education produces high quality human resources. However, the existence of gender gap in society causes low participation of women in education compared to men. This phenomenon happens due to various factors such as government policy, socio-economic, and culture. As such, this study aims to estimate the rate of return of gender-based school in Indonesia using Mincer earnings function. This study uses database Indonesia Family Life Survey (IFLS) 4 and 5. The two-step Heckman model of ordinary least square (OLS) is used for data analysis. The findings of this study are as follows. First, return to schooling is higher for male than female, for both service and manufacturing industries. Second, years of schooling, years of schooling interaction with manufacturing industril, years of schooling interaction with in service industril, the squared years of schooling interaction with manufacturing industril, the squared years of schooling interaction with service industril, gender interaction with service industril, gender interaction with manufacturing industril and urban/rural location are significantly influence return to schooling. While, squared years of schooling is not significantly influence return to schooling.
\end{abstract}

Keywords: mincerian earnings function, gender, return on schooling, two step heckman model

\section{Introduction}

Education is a longterm investment, in term of educational investments that considered as a commodity in economical perspective. This brought an understanding that knowledge and skill mastering, also skills and expertise owned by certain persons can be measured from economical value that can be returned in certain period of time through various occupancies based on the competencies (Faridah, 2015).

Education fully affects the economical growth of a nation. This is not because the education will affect productivity, but will also affect the fertility of the society (Mappalotteng, 2010). Previous theories had declared that the higher education level of a person will be shown in higher skills and knowledge, thus will be more productive, and that will lead to a higher income received in return of that productivity increasing. Furthermore, Mulyani stated that in aggregate, the education will be increasing economical development through the increasing of productivity of labor. Therefore the economical benefits from education will not only benefit the individu, but also for the society. Furthermore, Human Capital theory considered that people with higher education level are most likely have more skill and productivity compared to those with lower education level. So that with higher education level the individu can achieve higher income.

This theory is supported by several previous researchs. Research of Camoy (1967) showed that faster investment in education is not an adequate condition for economical growth; and that in average return rate of education are commonly higher compared to the return rate of physical capital, but both of the aspects are positively related. Deliakor (1993) find that return rate of educational investment in Indonesia is bigger in older age group compared to the younger group, and that woman in Indonesia had achieved higher education level compared to the man group. One assumption is that gender difference in investment return of education is the result of manufacturing technology in Indonesia. If working in the factory required physical strength to increase the productivity, than wage of man worker of the factory for under skilled and lower education level will be higher, whereas the return rate of education investment in basic level of woman is higher than the man group.

Miller (1997) found in Australia that genetically, family background and education will determine the wage level for man and woman in labor market; whereas return rate of education investment of woman is bigger, as for the family background influence is bigger in man group, and there is no difference in term of genetic. Next is 
Deschenes (2007) found that man raised in big household most likely have smaller opportunity to receive education, whereas the education level of parents is significantly affecting the return rate of educational investment.

As for provinces in Indonesia, the literacy level in 2013 is $93,25 \%$ and average period of education is 8,08 years. It means that there is still illiteracy in Indonesia. Average level of education in Indonesia is second grade of junior high school. Provinces in Indonesia are in number 9 in term of human resources quality in Indonesia. Education index of provinces in Indonesia shown by literacy level of 97,16\% in 2011 and 97,23\% in 2012, as for average education period in 2011 and 2012 each 8,57 years and 8,60 years.

Thus, from the education perspective there is still illiterate Indonesian approximately $3 \%$ annually. In addition, from the perspective of education period of people in provinces of Indonesia is average until grade 8, meaning that the educational completion level is in second year of junior high school. It shows the low level of education in Indonesia. But according to BPS, the education condition of Indonesia in 2012 is better than 2011. The data show that individu in range of $7-24$ years old that still in schooling process, according to age and sex group is only $75,29 \%$. It means that approximately $25 \%$ is not in schooling process. As for in age group of $19-24$ years of, the percentage of individu that pursuing education is only $27,64 \%$.

Several previous result of research are different from the data discovered in provinces of Indonesia, shows that school participation level of woman in Sumatra Barat is higher. It shows that woman group has bigger opportunity to acquire higher income. This condition is shown by percentage of woman in age $7-24$ years old that still in school is approximately $76,77 \%$ which is higher compare to man group that only $73,86 \%$. Furthermore, based on region, population of age $7-24$ years old that still in school process is $77,21 \%$ in city areas, as for village areas is approximately $74,02 \%$. This research is aimed to find determinant of return rate of educational investment and how much the return rate of individual education investments based on gender in Indonesia.

\section{Theoretical Frame}

\subsection{Human Capital Theory}

Basic assumption of Human Capital theory is that a person can increase their income through education development. For every year of education, means that there are increasing of working ability and income level; but on the other side, postponing a year of income in order to stay in school. Besides the postponing of receiving income, that individu must pay in advance for the education cost. Therefore the income received will be calculated in present value. The present value can be divided in two options, that is if the education until high school level or procede to university before start to work (Bruce E. Kaufman and Julie L. Hotchkiss in Atmanti (2005)).

Present Value for high school education level is:

$$
P V=Y_{t}^{H}+\frac{Y_{19}^{H}}{(1+i)}+\frac{Y_{20}^{H}}{(1+i)^{2}}+\cdots+\frac{Y_{64}^{H}}{(1+i)^{46}}=\sum_{t=18}^{64} \frac{Y_{t}^{H}}{(1+i)^{t-18}}
$$

Present Value from a lifetime earning should a person working for 46 years, from 18 years old until 64 years old. $\mathrm{Y}$ is earned income after graduated from university in year $\mathrm{t}, \mathrm{C}_{1}$ is direct cost during university, and $\mathrm{i}$ is current interest applied. Meaning that a high school graduated individu will earn in age 18 or 22 years old for university graduated, will first choose to continue the education with hope that they will earn better income in the future (opportunity cost).

\subsection{Investment Decision}

Quality improvement of human capital requires long period of time. Human capital investment is considered same with other production factors investment. Rate of return (benefits) of investment on human capital is also calculated. When a person will invest, that person must first make a cost benefit analysis. The cost is expenses that must be made to attend a school, and opportunity cost of school attending is earned income when that person decided not to continue the education. As for the benefit is income (return) that will be received in the future after school. By investing, the individu is expecting bigger earning compare to the cost.

Based of human capital investment perspective, a decision to start work immediately or to continue the education in university must be first based on received benefit compared to the cost during university education. Atmanti (2005) showed that there are 2 investing strategies, (a) finish the high school (in 18 years old) and immediately decided to work until 65 years old. It described by High School curve. (b) Procede to university after high school at 18 years until 21 years old and start to work in 22 years old until 65 years old. It described by university curve.

Costs to continue education in university are considered 2 types. First is direct cost including tuition fee, books 
and other expenses (including living cost if the education is taking place in out of town or even abroad). The illustration showed that direct cost is in area b. the amount of direct cost is depend on various factors, for example: whether enroll to state of private university, whether the individu receiving scholarship, and many other. Second type is opportunity cost when a person procedes to university, which is lost income because attending university. This opportunity cost described in area a. the amount of lost income is depending on whether job taken is part time or full time.

Benefit earned from procede to university education is future bigger income according to education level received. There is an income difference between high school graduated and university graduated, the illustration showed that high school curve is declining and eventually below the university curve. As the university curve is raising.

\subsection{Benefit and Social Cost as well as Benefit and Individual Cost}

Social cost is opportunity cost that must be taken entirely by society as a result of need or availability to finance expensive higher education expansion, using money that might become more productive if used in other sectors of economy. There will be disparity between social cost and individual cost, there for will trigger bigger demand on higher education. But the creation of opportunity to receive higher education will cause surge of social cost that paid by society. The society must also pay for social cost in term of degenerating of resources allocation that eventually will reduce the saving and opportunity to create direct working opportunity or to continue other development programs. Bit by bit, higher education will become the purpose, instead of a tool (Michael P. Todaro, 2000).

Benefit and social cost as well as benefit and individual cost can be described as that the higher education of the individu, than the higher expected income compared to individual cost is. To maximizing difference between expected income with estimated costs (private rate of return to investment in education), the available optimum strategy for the concerned individu is by trying to achieve high education as possible. the social benefit curve that was initially sharply increased. This illustration is describing the improvement of productivity level from individu with basic education. There is social benefit curve that keep increasing according to the increasing of education level despite the decling improvement pace. On the contrary, social cost curve is showing low improvement level in early years of education level, and eventually grow faster for higher education level.

According to Borjas (2000), earning profile of certain education level is described by age earning profile curve. Illustration 4 showing that age earning profile curving slope is upward (upward sloping). This is caused by worker that invests bigger in human capital when they were younger. One of cost spent to make human capital investment came from foregone earnings that are earning that lost or decreased because a person doesn't work. The result is low income earns by worker in their younger age. The incomes will gradually increasing over age, because older worker will invest less in human capital therefore they have lower foregone earning. Beside, income of older worker also will rise because these workers had enjoyed benefit or return rate from education investment they had made previously.

\subsection{Gender Preferences in Education}

According to Schultz in Budiarti (2010), there are 3 factors that motivate parents to prioritize education for sons compare to daughters. (1) Investment return rate for woman considered lower compared to man. (2) Remittance of daughter's considered lower compared to sons. (3) Bigger satisfaction of parents to witness the success of sons instead of daughters.

Bouiss and Haddad in Todaro (2006) explained that expanding education opportunity for women will actually economically benefit for reasons as follows: (1) return rate of education from women are higher than men in most developing countries. (2) Education improvement for women will not only increase productivity in farming field and factory work, but will also increase labor participation, later marriage, lower fertility and nutrition improvement for children. (3) Better health and nutrition quality and educated mothers will provide doubling effects to the quality of children for many generations to come. (4) Women carries the biggest burden of poverty and scarcity of farming land in most developing countries, therefore a significant improvement of women through education will have high impact to cut the vicious cicle of poverty and inadequate education. Based on that opinions we can see the importance of education for women in order to increase the quality of generations to come. 


\section{Method}

\subsection{Education Rate of Return by Mincer Income Function}

This research is aimed to estimate the level of investment return of education for both man and woman that has completed their education by using datas provided by SUSENAS. Models used to estimate the return rate is adopting model used by Deolalikar (1993) as follows:

$$
\ln E_{i}=\propto^{j}+\sum_{d} \beta_{j}^{d}\left(A_{i}\right) D_{i d}+\gamma^{j} A_{i}+\lambda^{j} A_{i}^{2}+\varepsilon_{i}^{j}
$$

Whereas $\mathrm{I}$ is index of individu and $\mathrm{j}$ is index of gender. Ln $\mathrm{E}$ is natural algorithm of income (Present Earning), $D_{\text {id }}$ is years of schooling, $A$ is age and $A^{2}$ is squared age that showing diminishing return of human resources quality. Assumption used in OLS method is $\mathrm{E}(\varepsilon)=0$, meaning that worker's wage will be randomly distributed. But data of wage will only available for those who participate in labor market and earn their income. As for those who don't participate in labor market because their expected income don't match with company's offering or for the workers who don't get paid, the wage or income's data are not available.

Because there is bias possibility in sample choosing, the research is using Heckman method (1979) as quoted in research conducted by Budiarti (2010). According to Heckman, before estimating the amount of education investment return rate of income function of Mincer, first calculation must be done to count the probability of a person to work for income that based on certain characteristic. For that, on the first phase the working participation probability of respondent will be estimated using probit model. From analysis of this phase there will be estimation amount of $\lambda$ variable that commonly named as inverse mills ratio. This is to overcome the sample-selection bias problems.

The estimation result of correction factor of inverse mills ratio $(\lambda)$ which is gained from first phase analysis that later inserted intoMincer function equation as the free variable. The result of change of previous equation as follows:

$$
\ln E_{i}=\propto^{j}+\sum_{d} \beta_{j}^{d}\left(A_{i}\right) D_{i d}+\gamma^{j} A_{i}+\lambda^{j} A_{i}^{2}+\gamma^{j} Z+\gamma^{j} \lambda+\varepsilon_{i}^{j}
$$

Whereas $\mathrm{Z}$ are other controlling variables that considered affecting the amount of income, such as living location, working hours, marital status and partner's age, as $\lambda$ are correction factors of inverse mills ratio. Data using in this research is cross section data that had been processed by using Ordinary Least Square method, that is searching the smallest quadrate of error. Regression conducted by looking for relation between one tied variable and several free variables, known as Multiple Regression. Multiple regression required several assumptions to ensure the estimator is BLUE (Best Linear Unbias Estimator). Based on previous explanation, the analysis probit model of worker's participation level as follows:

$$
\mathrm{Z}=\mathrm{b}_{\mathrm{o}}+\mathrm{b}_{1} \text { age }+\mathrm{b}_{2} \text { age }^{2}+\mathrm{b}_{3} \mathrm{JK}+\mathrm{b}_{4} \mathrm{SP}+\mathrm{b}_{5} \text { Baby }+\mathrm{b}_{6} \text { Wealth }
$$

$\mathrm{Z}$ is worker's participation, Age is the respondent's age, JK is gender, SP is marital status, Toddler is the number of children in the household, Wealth is amount of possession.

As for two step heckman model for return of education investment as follows:

Ln W $=b_{o}+b_{1}$ edu $+b_{2}$ edu ${ }^{2}+b_{3}$ eduind $+b_{4}$ eduserv $+b_{5}$ edu ${ }^{2}$ ind $+b_{6}$ edu ${ }^{2}$ serv $+b_{7} j$ jkind $+b_{8}$ jkserv $+b_{9}$ geo

$$
+\lambda
$$

Whereas $\mathrm{W}$ is wage, Edu is schooling period, $\mathrm{Edu}^{2}$ is quadrate of schooling period, Eduind is interaction between schooling period with industrial business field, Eduserv is interaction between schooling period with service business field, Edu ${ }^{2}$ ind is interaction between schooling period with service business field, Jkind is interaction between gender with industrial business field, Jkserv is interaction between gender with service busines field, Wilayah is living location of respondents and $\lambda$ is correction factor variables / inverse mills ratio. To test the significantly level of each eksogen variables partially toward the endogent variable, $Z$ test was conducted with $Z$ test criteria if $Z_{0} \geq Z$ tab atau $-Z_{0}<-Z_{\text {tab }}$, or prob $<\alpha$ then Ho rejected dan Ha accepted, and if $\mathrm{Z}_{0}<\mathrm{Z}_{\text {tab }}$ or $-\mathrm{Z}_{0} \geq-\mathrm{Z}_{\mathrm{tab}}$ or prob $>\alpha$ then Ho accepted dan Ha rejected.

Data in my paper use data base Indonesian Family Life Survei (IFLS) four (4) and five (5). The Indonesian Family Life Survey (IFLS) is an on-going longitudinal survey in Indonesia. The sample is representative of about $83 \%$ of the Indonesian population and contains over 30,000 individuals living in 13 of the 27 provinces in the country. The IFLS surveys and their procedures were properly reviewed and approved by IRBs (Institutional Review Boards) in the United States (at RAND) and in Indonesia at the University of Gadjah Mada (UGM). 


\section{Result and Analysis}

\subsection{Analysis of Working Participant with Income}

Table 1 showing regression results of Probit and Marginal Effect of Working Participants with Income in Indonesia. The calculation result is showing that age variable, age2, whether there is toddler in the household and wealth are significantly affecting to working participation in Indonesia. As for gender and marital status is not significantly affecting working participation with income.

Table 1. Regresion result and marginal effect labour partisipation

\begin{tabular}{lllll}
\hline Variabel & Coef & Marginal effect & $\mathbf{Z}$ & $\mathbf{P}>|\mathbf{z}|$ \\
\hline Umur & 0.059 & 0.019 & $9.070^{* * *}$ & 0.000 \\
umur $^{2}$ & -0.001 & 0.000 & $-12.180^{* * *}$ & 0.000 \\
Gender (JK) & -0.004 & -0.001 & -0.200 & 0.841 \\
Maried Status (SP) & -0.030 & -0.010 & -1.000 & 0.316 \\
Baby (BLT) & -0.132 & -0.043 & $-5.820^{* * *}$ & 0.000 \\
Wealth (W) & 0.547 & 0.198 & $19.250^{* * *}$ & 0.000 \\
Constant & -1.260 & & $-11.000^{* * *}$ & 0.000 \\
\hline
\end{tabular}

Sumber: Data diolah 2014

Ketr. ***: sig pada $\alpha=0.01$

$* *$ : sig pada $\alpha=0.05$

* : sig pada $\alpha=0.10$

Age is positively and significantly affecting the level of working participation with income. Meaning that the older a person is then the working probability is higher, and vice versa. However, the influence of age 2 to participation level is negative. Thus, age 2 mean that the older a person is then there is decline of working opportunity with income until certain age, and then will rise according to the age.

The finding of this research is in accordance with the opinion of Borjas (2000), income through certain education level described by age earning profile curve that tends to upward sloping. It is because workers had invested bigger in human capital during their younger age. One of cost to invest in human capital came from foregone earnings, which is lost or decreased income because out of work. The result is low income received in their young age.

Income that will be received will increase paralle with age, because older worker will invest less on human capital therefore will have lower foregone earning. Beside that, income of older worker will be higher because those worker enjoying benefit or return rate of education investment they had done in younger age. The peak age of a person to participate working with income can be using first derivative of equation 5 .

$$
\frac{\delta \text { Labour Parisipation }}{\delta a g e}=0.059-0,002 \text { age }=0.6
$$

Age $=30,4$ tahun

When a person above 30,4 years old, there will be increasing opportunity to participate in working area. This condition is parallel with condition based on data that after marriage, the participation level of man is higher compared to woman. The higher education level of a woman is, the working participation will be higher compared to the woman with lower education level.

The gender is negatively affecting and unsignificant to working participation in Indonesa. Working participation of man is lower compared to woman, shown with marginal effect score of $-0,001$. Meaning that the possibility of man to participate in working area will decrease $-0,001$ point or $0,1 \%$. It also indicates that the opportunity for woman to work with income will be bigger. The result of this research is match with the findings that education participation level of women is bigger. So that when woman is in higher education level they will choose to work with income instead of not working or working without income. The unsignificantly effect of gender toward working participation can be seen in data that percentage of woman and man that don't work is quite small. 
Marital status is negatively affecting but unsignificant toward working participation with income in Indonesia. When the status is married then the working opportunity with income will decline about $1 \%$. The unsignificant effect of marital status toward working participation with income in Indonesia is according to data that there is not enough significant difference working participation with income between man and woman with married status and out of work. Besides, the higher participation level of woman that procede their education had caused higher level of working participation with income.

Toddler variable is negatively affecting and significant toward working opportunity with income. When toddler is in the household, the working opportunity to work wih income will decline up to $4,3 \%$. This is usually happened to married women with double roles as housewives and worker. Many of women who had toddler decided to quit their job, it caused time to work will be shorter compared to the time when they were still single.

Wealth variable that indicated by vehicle ownership status is positively affecting the working participation with income. When a person is in possession of wealth, then the working opportunity with income will be higher up to $19,8 \%$. It means that when a household is own a car then there will be need to fulfill the bigger transportation cost and recreational needs, thus encourage a bigger working opportunity.

The result of this research is contrary to research of Handayani (2006) in Budiarti (2010). It mentioned that to be able in position of not working, a person must have certain wealth, thus working probability for those with wealth will be smaller nevertheless, this condition is not applicable for provinces in Indonesia. The status of vehicle ownership as proxy wealth will cause bigger opportunity to work. The condition was also supported by bank and other institution's policy regarding purchasing system of car by installment, this is triggers the need to increase their income that eventually will increase the working probability.

\subsection{Return Rate of Education Investment}

The return rate of education investment is comparison between total cost spent to finance education and total benefit or income will be earned by the graduates. The return rate of education investment is divided into personal return rate and social return rate (Budiarti 2010). Based on estimation table 2, value of lambda $(\lambda)$ or significant correction factor variable is inserted into model to eliminate sample selection bias that happened because of sample selection issue.

Table 2. Result regresion two step heckman retrun on investment education

\begin{tabular}{|c|c|c|c|}
\hline & Variabel & Coef & $\mathbf{P}>|\mathbf{z}|$ \\
\hline \multicolumn{4}{|l|}{ LnWage } \\
\hline & Edu & 0.0542 & $0.002 *$ \\
\hline & $e d u^{2}$ & 0.0008 & 0.571 \\
\hline & edu_ind & -0.1215 & $0.000 *$ \\
\hline & Eduserv & -0.0969 & $0.000 *$ \\
\hline & edu ${ }^{2}$ ind & 0.0063 & $0.001 *$ \\
\hline & edu_ ${ }^{2}$ serv & 0.0058 & $0.000^{*}$ \\
\hline & Jkind & 0.6915 & $0.000 *$ \\
\hline & Jkserv & 0.4369 & $0.000^{*}$ \\
\hline & d_kota_desa & 0.2063 & $0.000 *$ \\
\hline & Constant & -1.260 & $0.000^{*}$ \\
\hline \multirow[t]{7}{*}{ D_TPB } & Age & 0.0588 & 0.000 * \\
\hline & $\mathrm{age}^{2}$ & -0.0010 & $0.000 *$ \\
\hline & d_jk_lk_pr & -0.0042 & 0.841 \\
\hline & d_maried & -0.1317 & 0.316 \\
\hline & d_baby & -0.1317 & $0.000^{*}$ \\
\hline & d_wealth & 0.5466 & $0.000 *$ \\
\hline & Constanta & -1.2605 & $0.000^{*}$ \\
\hline \multirow[t]{3}{*}{ Mills } & Lambda & 0.2229 & $0.000 *$ \\
\hline & Rho & 0.2884 & \\
\hline & Sigma & 0.7729 & \\
\hline
\end{tabular}

* Significant

The schooling period is affecting significantly to income linearly, but not significant as quadrate. Meaning that 
the higher education level of a person is then there is bigger return rate of education investment gained. This is relevant with opinion of Bruce E. Kaufman and Julie L. Hotchkiss in Atmanti (2005), every additional year of education mean that increasing working ability and income level of a person. But on the other hand, it will postpone the income earning for 1 year during schooling process. Besides postponing of income earning, a person that continue their education must pay the education fee in advance. Therefore the income amount will be received during their lifetime will be calculated in present value (Net Present Value). Present Value can be divided into two categories, with education until high school and proceding education to university before start to work.

This is supported by opinion of Todaro (2000) in benefit and social curve that initially sharply raising. This is illustrating the improvement of productivity level of those with basic education level. Next is social benefit curve that continue to rise according to the raise of education level, despite the slowing improvement rate. On the contrary, the social cost curve showing lower improvement rate in early years of basic education and that growing faster for higher education level.

The unsignificantly length time of school multiplied toward return rate of education declared that the higher education level until certain stage will not caused decline in return rate of education investment in Indonesia. This is according to return to schooling result described in chart 3. This research is contrary to research conducted by Deschenes (2007) that schooling length time multiplied is negatively significant affecting return rate of education investment.

In term of interaction, variables of school period and labor market is negatively significant linearly and positive quadratically. Based on estimation result of interaction variable of schooling period (edu) with labor market is negative, both in industry and service business. The interaction regression coefficient of schooling period with industry field is $-0,1215$ ot $-12,15 \%$, meaning that the higher education level of worker in industrial sector is then will be $12,15 \%$ lower for those with lower education level. The interaction regression coefficient of schooling period with service business field is $-0,0969$ ot $-9,69 \%$, meaning that the higher education level of worker in service sector is then will be $9,69 \%$ lower for those with lower education level.

Nevertheless, quadratically it shows positive relation. Meaning that the higher education until certain level is, the return rate of education investment will be lower. But when the education leved is rising, then it will increase the return rate of education investment both in industrial and service business field, as shown in chart 4 .

The return rate value of education investment according to the business field of respondents as table 3 :

Table 3. Estimation return investment on education based on work field

\begin{tabular}{llll}
\hline Long Years School & Industry & Service & Agricultural \\
\hline $\mathbf{0}$ & -0.07 & -0.04 & 0.05 \\
$\mathbf{1}$ & -0.05 & -0.03 & 0.06 \\
$\mathbf{2}$ & -0.04 & -0.02 & 0.06 \\
$\mathbf{3}$ & -0.02 & 0.00 & 0.06 \\
$\mathbf{4}$ & -0.01 & 0.01 & 0.06 \\
$\mathbf{5}$ & 0.00 & 0.02 & 0.06 \\
$\mathbf{6}$ & 0.02 & 0.04 & 0.06 \\
$\mathbf{7}$ & 0.03 & 0.05 & 0.07 \\
$\mathbf{8}$ & 0.05 & 0.06 & 0.07 \\
$\mathbf{9}$ & 0.06 & 0.08 & 0.07 \\
$\mathbf{1 0}$ & 0.07 & 0.09 & 0.07 \\
$\mathbf{1 1}$ & 0.09 & 0.10 & 0.07 \\
$\mathbf{1 2}$ & 0.10 & 0.12 & 0.07 \\
$\mathbf{1 3}$ & 0.12 & 0.13 & 0.08 \\
$\mathbf{1 4}$ & 0.13 & 0.14 & 0.08 \\
$\mathbf{1 5}$ & 0.15 & 0.16 & 0.08 \\
$\mathbf{1 6}$ & 0.16 & 0.17 & 0.08 \\
\hline
\end{tabular}

Source: Data diolah 2014.

Table 3 showing that the higher education level is, the return rate of education investment is in service field in amount of $17 \%, 16 \%$ for industrial, and the lowest is agriculture field of $8 \%$. In industrial sector the return rate 
of education investment will be achieved after schooling period of 6 years or graduated of elementary school for $2 \%$. But for service field industry, the return rate of education investment achieved in 4 years of schooling period is $1 \%$. Therefore, for those who stopped their education in elementary school are prefer to work in agricultural sector with return rate of education investment above $4 \%$.

When a person only have diploma of elementary, it is best choice to choose agricultural sector as working field because the return rate of education investment is the highest, around $6 \%$. But when a person have junior high school diploma, it is better to choose service field with highest return rate of $8 \%$. The same is applied for high school and university level.

Furthermore, considering gender and business field is affecting positively and significant to the received income. Man will chooce higher income when working in industrial sector instead of service, with regression coefficient each 0,6915 and 0,4369 . This mean that income of man that working in industrial sector is $68,15 \%$ higher compared to woman on the same sector. As in service sector, the income of man is $43,69 \%$ higher compared to woman in the same sector.

It shows that return rate of education investment for man is higher compared to woman. The result is different with several research of Miller (1997), it discovered that the return rate of investment for woman is higher compared to man. Besides, as quoted by Todaro (2000) that the return rate of education for woman is higher compared to man in most developing countries. But judged by the participation level of working, woman have bigger opportunity to work compared to man in Indonesia.

Next is, living location is positively affecting and significant toward income. It mean that those who live in city areas will have $20,63 \%$ higher return value compared to those who lives in village area. The positive result of income return with living location in city areas was caused by migration move of the people with higher education level. According to Farahnasy in Budiarti (2008), there are three reasons that there are bigger earning in cities : (a) higher productivity level in cities compared to those in villages. (b) Higher quality of workers in the cities compared to those in villages, it is understandable because education levels of worker in cities are relatively higher. This is because people lives in the cities have better and easier access to education and transportation facility necessities. (c) cash turnover and economical activities tends to concentrate in city areas, because it considered to affect the convenience to earn bigger income and profit level. It will affect the decision of companies to enhance the welfare of their worker through income increasing for worker with potentials. Thus, investment return rate for people in cities are bigger compared to those who lived in villages.

\section{Conclusion}

The conclusion of this research showed that (1) age variable, toddler and wealth are significantly affecting the working probability to earn income. Gender and marital status are not significantly affecting working probability to earn income. (2) Schooling period. Interaction between schooling period with industrial business field, interaction between gender and industrial business field, interaction between gender and service business field, living area is significantly affecting toward education investment return rate of population between $15-64$ years old. Schooling period quadrately is not significantly affecting toward education investment return rate of population between $15-64$ years old. The implication of this research is even distribution of education and working opportunity for both man and woman.

\section{Acknowledge}

We are thank to center for research and publication Faculty Economic and Business Airlangga University were funded this research. Researchers operated independently from the funders on this work, and funders neither provided nor were required to provide review and approval of this research.

\section{References}

Angraini, D. (2006). Pengaruh gender pada tingkat pengembalian investasi pendidikan. (Tesis). Depok: Universitas Indonesia.

Arkes, Jeremy. (2010). Using Unemployment Rates as Instruments to Estimate Returns to Schooling. Southern Economic Journal, 76(3), 711-722. Retrieved from http://www.jstor.org/stable/27751493

Ashenfelter, O., \& Alan, K. (1994). Estimates of the Economic Return to Schooling from A New Sample of Twins. The American Economic Review, 84(5), 1157-1173. Retrieved from http://www.jstor.org/stable/2117766

Atmanti, Hastarini Dwi. (2005). Investasi sumber daya manusia Melalui pendidikan. Jurnal Dinamika pembangunan. 
Blackburn, M. L., \& David, N. (1991). Omited - Ability Bias and the Increase in the Return to Schooling. Working Paper, 3693.

Blackburn, M. L., \& David, N. (1995). Are OLS Estimates of the Return to Schooling Biased Downward? Another Look. The Review of Economics and Statistics, 77(2), 217-230.

Borjas, G.J. (2000). Labor Economics. Amerika: McGraw-Hil.

BPS. (2013). Sumbar dalam Angka 2013. Padang: BPS

Budiarti, N. (2010). Analisis Tingkat Pengembalian Investasi Pendidikan di Provinsi Nanggroe Aceh Darussalam.

Card, D. (2000). Estimating the Return to Schooling: Progress on Some Persistent Econometric Problems. Working Paper, 7769.

Carnoy, M. (1967). Rates of Return to Schooling in Latin America. The Journal of Human Resources, 2(3), 359-374.

Ciccone, A., Federico, C., Piero, C. \& Riccardo, F. (2004). The Private and Social Return to Schooling in Italy. Giornale degli Economisti e Annali di Economia, Nuova Serie, 63(3/4), 413-448. http://www.jstor.org/stable/23248172

Deolalikar, A. B. (1993). Gender Differences in the return to schooling and school enrolment rates in Indonesia. Journal of Human Resources, 28(4), 899-932.

Deschenes, O. (2007). Estimating the Effect of Family Background on the Return to Schooling. Journal of Business \& Economic Statistics, 25(3), 265-277.

Dougherty, C. (2005). Why Are the Returns to Schooling Higher for Women than for Men? The Journal of Human Resources, 40(4), 969-988.

Faridah. (2015). Kajian tentang Rate of Return Perguruan Tinggi dan Implikasinya pada Peningkatan Mutu Pembelajaran. Jurnal Penelitian dan Wacana Pendidikan, 9(1).

Gujarati, D. N. (2003). Basic Econometrics (4th ed.). McGraw-Hill.

Harmon, C. W. (1995). Estimates of the Economic Return to Schooling for the United Kingdom. The American Economic Review, 85(5), 1278-1286.

Heckman, J. J. (2003). Empirical Estimates of the Returns to Schooling. University of Chicago and The American Bar Foundation.

Isacsson, G. (2004). Estimating the Economic Return to Educational Levels Using Data on Twins. Journal of Applied Econometrics, 19(1), 99-119.

Mappalotteng, A. M. (2010). Keuntungan investasi pada berbagai tingkat pendidikan Di Provinsi Sulawesi selatan Jurnal MEDTEK, 2(1).

Miller, P., Charles, M., \& Nick, M. (1997). Family Characteristics and the Returns to Schooling: Evidence on Gender Differences from a Sample of Australian Twins. Economica, New Series, 64(253), 119-136.

Nordin, M. (2008). Ability and Rates of Return ti Schooling - Making Use of the Swedish Enlistment Battery Test. Journal of Population Economics, 21(3), 703-717.

Todaro, M. P. (2000). Pembangunan Ekonomi di Dunia Ketiga (Terjemahan Haris Munandar). Erlangga. Jakarta.

Trostel, P. (2002). Estimates of the economic return to schooling for 28 countries. University of Maine: USA.

Wong, K. C., Raymond, L., \& Ho, Lai-Ming, (2002). The Effects of Schooling on Gender Differences. British Educational Research Journal, 28(6), 827-843.

\section{Copyrights}

Copyright for this article is retained by the author(s), with first publication rights granted to the journal.

This is an open-access article distributed under the terms and conditions of the Creative Commons Attribution license (http://creativecommons.org/licenses/by/4.0/). 